\title{
O REAL, O VIOLENTO E A VINGANÇA NO CONTO "PUTAS ASESINAS", DE ROBERTO BOLAÑO
}

\begin{abstract}
Andre Rezende Benatti ${ }^{1}$
RESUMO: Este artigo tem como objetivo empreender uma análise do conto "Putas Asesinas", de Roberto Bolaño, presente na coletânea de contos também intitulada Putas Asesinas, publicado pela primeira vez em 2001. O conto nos mostra a narrativa de uma prostituta e o seu envolvimento com um homem chamado Max, assim como a tortura e morte da personagem. Na análise abordaremos questões que giram em torno da violência e vingança presente no conto. Xavier Crettiez (2009), afirma que definir a violência como um conjunto de temas e feitos que se assemelham facilmente é impossível, pois a violência se apresenta das mais múltiplas formas. No conto, percebemos os estratos da violência enquanto parte integrante do aparato social, sem a qual, talvez, não seria possível a sociedade existir, assim como parte do próprio homem, nesta medida nos focaremos nas atitudes que levaram a personagem principal do conto a vingar-se de Max. Para tal leitura tomamos como base, para além de conceitos críticos e teóricos relativos à estética literária, também nos aportaremos em estudos relativos à perversidade, crueldade e violência, tais como A parte obscura de nós mesmos: uma história dos perversos, de Elisabeth Roudinesco, La ética de la crueldade, de José Ovejero, Literatura e Violência, de Ronaldo Lima Lins, Las Formas de la Violencia, de Xavier Crettiez e Literatura, violência e melancolia, de Jaime Ginzburg, entre outros.
\end{abstract} PALAVRAS-CHAVE: Violência; vingança; Putas Asesinas; Roberto Bolaño,

ABSTRACT: This article aims to undertake an analysis of the story "Putas Asesinas", by Roberto Bolaño, present in the collection of short stories also titled Putas Asesinas, first published in 2001. The story shows the narrative of a prostitute and his involvement with a man named Max, as well as the torture and death of the character. In the analysis we will address issues that revolve around the violence and revenge present in the story. Xavier Crettiez (2009), affirms that defining violence as a set of themes and feats that are easily resembled is impossible, since violence presents itself in multiple forms. In the story, we perceive the strata of violence as an integral part of the social apparatus, without which, perhaps, it would not be possible for society to exist, as well as part of man himself, to this extent we focus on the attitudes that led the main character of the story to avenge In addition to critical and theoretical concepts related to literary aesthetics, we will also contribute to studies related to perversity, cruelty and violence, such as A parte obscura de nós mesmos: uma história dos perversos, by Elisabeth Roudinesco, La ética de la crueldade, by José Ovejero, Literatura e Violência, by Ronaldo Lima Lins, Las Formas de la Violencia, by Xavier Crettiez e Literatura, violência e melancolia, by Jaime Ginzburg, among others.

KEYWORDS: Violence; Revenge; Putas Asesinas; Roberto Bolaño.

1 Professor de Literatura Espanhola na Universidade Estadual de Mato Grosso do Sul - UEMS e do Programa de Pós-graduação em Letras da UEMS e em Estudos de Linguagens da UFMS. E-mail: andre_benatti29@hotmail.com 


\section{Uma perspectiva realista da violência narrada}

No Dicionário de termos literário Massaud Moisés grafa o verbete Realismo, como aquilo que, de maneira geral, "designa toda tendência estética centrada no "real", entendido como a soma dos objetos e seres que compõe o mundo concreto e social." (2004, p. 378). A partir do pensamento de Moisés (2004), podemos perceber o realismo como possível de se realizar em escritas literárias desde os primórdios da Literatura. Ora, se há algum objetivo em um texto literário, talvez seja a representação do real, da realidade empírica, esta, claro, de acordo com a perspectiva de cada época.

De acordo com Maria Teresa Gramuglio, em Império Realista (2002), representar o real se constrói como o objetivo central da obra de arte literária em prosa. Percebemos, aqui o realismo enquanto uma atitude que atravessa diversos séculos da Literatura, uma atitude que acompanha a humanidade. Bakhtin, em suas análises de A Cultura Popular na Idade Média e no Renascimento (2010), encontra nestes períodos, por exemplo, formas de representação da realidade. Contudo, o autor não concebe o realismo na literatura como mera temática que perpassa uma obra. Para Bakthin (2010), o realismo é estético. Assim, pretendemos explorar, tendo como objeto de análise o conto "Putas Asesinas", de Roberto Bolaño, as nuances que tendem, na literatura, à representação do real e da violência.

Conforme afirma Antonio Candido, em Literatura e sociedade (2014), procurar no texto literário o meio social, ou seja, esta realidade imediata, não se justifica por si só, pois literatura não é uma cópia da realidade real e, por isso, não serve para definir esse meio. O meio social só se torna relevante quando é uma parte interna da estruturação do texto, que integre e qualifique a própria narrativa, sendo possível revisitar as forças colocadas em choque na conformação social.

A literatura é uma instituição social que utiliza, como meio de expressão específico, a linguagem - que é uma criação social. Processos literários tão tradicionais como o simbolismo e o metro - são, por natureza, sociais. Constituem convenções e normas que só podiam ter surgido em sociedade. Acresce que a literatura "representa" a "vida": e a vida é, em larga medida, uma realidade social, não obstante o mundo da Natureza e o mundo interior ou subjectivo do indivíduo terem sido, também, objecto de "imitação literária" (WELLEK, WARREN, s/d, p.113)

Toda a realidade social que é representada na obra de arte literária existe antes e independente à obra. Assim, refletimos sobre uma literatura que exprime uma realidade social, que é representação do real. Voltando à Gramuglio (2002), representar a realidade, é pensar a representação estética desta sociedade. Aventamos a Literatura Latino-americana como um espaço no qual tal sociedade é permeada por uma violência visceral desde sua criação, especialmente os contos que compõe a coletânea Putas Asesinas (2017), de Roberto Bolaño, do qual extraímos a narrativa aqui analisada. Há uma violência sistemática ocorrendo na literatura produzida na América Latina ao longo de sua história e que perdura até a contemporaneidade.

Apesar disso, a sociedade representada na obra não é e jamais será a mesma sociedade 
que existe fora dela, pois, se há um objetivo da literatura, este não é representar a realidade empírica, o que há na obra literária é a construção um novo mundo, capaz de refletir parcial e opacamente a sociedade externa, porém seguindo seus próprios padrões e estruturas narrativas. E é desta sociedade, que desempenha algum papel na estrutura textual, que nos ateremos ao analisar as narrativas latino-americanas, como esta literatura internaliza e elege como estética narrativa a violência pertencente à sociedade externa ao objeto literário

[...] o que interessa é averiguar que fatores atuam na organização interna, de maneira a construir uma estrutura peculiar. Tomando o fator social, procuraríamos determinar se ele fornece apenas matéria (ambiente, costumes, traços grupais, idéias), que serve de veículo para conduzir a corrente criadora (nos termos de Lukács, se apenas possibilita a realização do valor estético); ou se, além disso, é elemento que atua na constituição do que há de essencial na obra enquanto obra de arte (nos termos de Lukács, se é determinante do valor estético). (CANDIDO, 2000, p.6)

Partindo do ponto em que a Literatura possui um contato extremamente estreito com a realidade externa a ela, contato este que oscila entre depender e se rebelar, Ronaldo Lima Lins (1990) afirma que, na compreensão da natureza literária se aceita o princípio de que a arte se revela tendo como uma de suas funções a mudança de alguma coisa em seu apreciador.

Assim, compreendemos o realismo, a partir do que é afirmador por Jakobson no ensaio Do realismo na arte (2013), que para além de outras acepções, afirma que o realismo "1. Trata- se de uma aspiração, de uma tendência, isto é, chamam realista a obra que o autor em questão projetou como verossímil. (Significado A). 2. Chamam realistas a obra que quem a julga percebe como verossímil. (Significado B) (JAKOBSON, 2013, p. 110). Partindo das assertivas de Jakobson (2013) expostas acima, percebemos que tais questões são latentes no conto de Bolaño. Toda a atmosfera criada pelo autor avança sobre a verossimilhança aristotélica trazendo a toma uma obra impactante e sufocante. Sentido, muitas vezes, pela construção textual, tudo aquilo que tanto a narradora quanto sua vítima sentem.

Roland Barthers, o ensaio Efeito de real (1971), afirma que a verossimilhança não é considerada uma característica absoluta do texto realista, pois, para o teórico, o relismo deve, também, seu conceito ao afastamento da busca incessante pela imitação da realidade proposta na liteatura.

O realismo não pode ser [...] a cópia das coisas, mas o conhecimento da linguagem; a obra mais 'realista' não será a que 'pinta' a realidade, mas a que, servindo-se do mundo como conteúdo (este mesmo conteúdo é, aliás, alheio à sua estrutura, isto é, ao seu ser), explora o mais profundamente a realidade irreal da linguagem. (BARTHES,1971, p.164)

Assim, percebemos no conto de Bolaño este efeito de real proposto por Barthes, por exemplo, na cena em que a narradora, logo no inicio do conto, afirma "Te vi en la televisión, 
Max, y me dije éste es mi tipo." (BOLAÑO, 2017, p. 111), fazendo com que o leito, a partir de então e até o final do conto, perceba, por meio da linguagem utilizada e das descrições feitas do sujeito, qual é o "tipo" de homem que a assassina busca. Todas as descrições do estádio de futebol e tudo que envolve este universo masculino, são parte da construção da projeção de realidade, pois são objetos irrelevantes para o enredo, mas que fazem parte da construção do espaço com características mínimas que é o que ocorre na realidade empírica, tal aspecto é o efeito do real projetado por Barthes.

\section{De uma América Latina violentada às narrativas violentas}

O conto na América Latina, mas não somente ele como também toda literatura produzida nesta região, tem profundo apego à violência. Parece banal ou até mesmo clichê dizer que, na atualidade, a América Latina como um todo passa por diversidades imensas de violências: governos que flertam com o autoritarismo, crises econômicas que retiram qualquer dignidade humana das populações, desastres "naturais", alguns deles provocados pelo homem, racismos, xenofobias, preconceitos de gêneros, etc.. Enumerar todas as violências que hoje atingem o subcontinente seria algo inimaginável em um artigo, tamanha a responsabilidade e desenvolvimento deste fenômeno na atualidade.

Contudo, tal fenômeno não tem sua origem no contemporâneo, para Martin Lienhard (1993), este continente americano ao qual os europeus se convidam a "descobrir", como estes mesmos afirmaram, não foi nem de longe um vazio cultural, pelo contrário, haviam aqui diversas comunidades coletivas e organizadas das mais diferentes formações. Algumas muito antigas e extremamente desenvolvidas, outras muito jovens e ainda iniciando seu processo de desenvolvimento. Contudo, estas comunidades coexistiam, por vezes de forma pacífica, em outras envolvidas em guerras e conquistas.

A violência, no continente americano, sempre existiu. O Éden terreno, com praias calmas, povos inocentes e ignorantes, onde "tudo o que se planta dá", representado por Cristovam Colombo e por Pero Vaz de Caminha, no caso brasileiro, em suas cartas de informação de "descobrimento" estava muito longe da realidade que se concretizada nas terras do Novo Mundo. Os conflitos entre as tribos eram normais, sejam elas grandes ou pequenas. Conforme podemos perceber nas Cartas de Relación, de Hernán Cortés, o famoso e grandioso Império Asteca era formado por diversas tribos menores que foram conquistadas, ou seja, violentadas e usurpadas de seus direitos em nome do poderio e da expansão dos Astecas, afirmando, assim, os conflitos existentes internamente, as violências que já existiam na América desde antes deste lugar se chamar América.

Gordon Brotherston em La visión americana de la conquista (1993), afirma que a conquista da América não se realizou de um dia para o outro, não se concretizou com a simples chegada de espanhóis, portugueses, ingleses e franceses ao Novo Mundo. A conquista também não acabou com as grandes e violentas vitórias de Cortés e Pizzaro, mas esta se trata de um fenômeno muito complexo que se arrastou, e persiste, desde o século XVI até o século XXI, ao menos. Ela foi sangrenta, e custou milhões de vidas e milhares de culturas. 
Tradicionalmente, para los que han tenido que enfrentarla, esta invasión ha significado pérdida total de bienes y de territorio, desplazamiento, esclavitud, e incluso exterminio definitivo. La fuerza misma del proceso invasor ha impedido que sus victimas tuvieran muchas oportunidades para representar literariamente dicho proceso, o para reflexionar sobre su significado filosófico. (BROTHERSTON, 1993, p. 65)

Assim, tendo as afirmativas de Brotherston (1993) como norte, podemos perceber que as marcas de tais perdas, escravizações, extermínios e dominações, se impregnaram na cultural que estava se formando na América. De tais embates entre conquistados e conquistadores, mesmo sendo subjugados e oprimidos, dos conquistados nasce uma gama de textos, principalmente orais, ou na língua no conquistados, em casos raros, que dão visão aos desastres que a experiencia causou. Contudo, estes textos nunca entraram na moda, nunca foram lidos pelo grande púbico. A representação de tais textos e vozes ressoa na resposta à inquietante pergunta que dá título ao ensaio de Gayatri Spivak, Pode o subalterno falar?, que seria "Sim, mas mesmo que responda, quem o ouvirá?".

Neste cenário de violência, criado e perpetrado no continente desde a Conquista e, durante os três primeiros séculos, agravado com a escravização negra, como poderíamos, nós latino-americanos, distanciar nossas narrativas de tais violências. Sejam elas quais forem, as violências se fizeram e ainda fazem parte do cotidiano nas América Latina.

Se fizermos uma historiografia da literatura de língua espanhola, poderemos perceber que, ao longo dos séculos, há uma tradição de representação da violência. Grande parte das mais renomadas obras da literatura de língua espanhola, seja ela peninsular ou americana, tem a violência e a crueldade enquanto partícipes de suas composições.

Todavia, para pensarmos na representação da violência na literatura, devemos, de alguma maneira, pensar na própria construção desta literatura. Enquanto um objeto social, a literatura somente cumpre seu papel por haver um sujeito escritor e um sujeito leitor que juntos. Baseando-se em uma série de estruturas como a língua, os códigos linguísticos em geral, o "conhecimento de mundo", as referências sociais, antropológicas e culturais escritor e leitor criam um sistema social específico e único, criado a partir de fatores externos ao literário, ou seja, a partir de uma sociedade humana.

Toda literatura tem como base uma sociedade humana, mesmo que esta não esteja representada. O homem é anterior à obra literária o que condiciona o próprio escritor à sociedade humana, representando-a.

O mundo hispânico, afirma José Ovejero (2012), tem, no que diz respeito à Literatura, a fama de ser um lugar com um gosto peculiar e particular por aquilo que é violento, por uma violência que é apresentada ao leitor com total naturalidade. Quando nos voltamos às narrativas espanholas do longo da história, podemos perceber que a Espanha "cria", de certa maneira, até mesmo um subgênero narrativo, o picaresco, que tem por essência, para além de outras questões, a violência.

Ao longo da história, a literatura de língua espanhola desenvolveu grande obras cruéis e violentas. Se o riso pode ser cruel, na literatura espanhola ele se desenvolve com grande maestria. Lazarrillo de Tormes é, sem sombra de dúvidas, uma obra que causa, na maioria 
das pessoas, o riso. As situações enfrentadas pela personagem principal, Lázaro, são cômicas. Todavia, se analisarmos seu contexto, percebemos a parcela cruel que a vida criada para Lázaro lhe impõe. O protagonista é um menino que, por passar fome junto à mãe, acaba virando pajem, no início, de um cego que não o alimenta e o espanca, "para que ele aprenda a viver", daí a outros amos tão ou mais cruéis, o desenvolvimento da personagem, ícone da literatura espanhola, passa todo por sofrimentos e privações.

Ao longo da literatura espanhola temos ainda, enquanto marcadamente violenta, por exemplo, a peça Fuenteovejuna, de Lope de Vega, a qual a crítica especializada julga enquanto a primeira aparição da violência justificando a própria violência. Na peça, um cruel comendador é morto, no ato de uma audiência pública de investigação do caso o juiz pergunta quem matou o comendador, e o coro da população responde, Fuenteovejuna.

Voltando a Ovejero (2012), percebemos que se fizermos,

[...] un rápido repaso a los grandes nombres de la literatura nos lleva de inmediato a cultivadores de lo bizarro y lo absurdo, de lo exagerado, y, en los casos más amables, de lo melodramático: Quevedo, Cervantes, Valle-Inclán, Cela, Bécquer narrador, Vila-Matas, cultivadores del exceso cada uno a su manera. Incluso Galdós, que pasa por realista, no puede escapar al gusto por los excesos sentimentales. (OVEJERO, 2012, p. 16)

No entanto, a crueldade, o exagero, a violência, não estão presentes apenas na literatura espanhola. A vida cotidiana hispânica é permeada por todos estes atos. Talvez uma das manifestações culturais espanholas mais conhecidas, a Tourada ou Corrida de Touros é um grande espetáculo de carnificina, grande manifestação do prazer oriundo da violência contra o outro. O espetáculo banhado a sangue e morte que atrai milhares de pessoas, tanto locais quanto turistas, que se deslocam até o país simplesmente para apreciar um grande espetáculo de violência.

La muerte como espectáculo para las masas, como diversión, como tradición, que debe ser conservada - o rechazada precisamente por quienes no quieren identificarse con "lo español" -; contemplar la tragedia mientras se fuma un puro, saborear el dolor (OVEJERO, 2012, p.17)

Na contemporaneidade, cada vez mais a crueldade, a violência, a perversão e a morte, transformadas em um grande espetáculo, ocupam o cotidiano. No entanto, cabe, neste caso, um questionamento, se todo o horror ocupa nosso dia-a-dia, haverá alguma parcela destas questões capaz causar incomodo a ponto de fazer-nos refletir sobre o assunto?

Partindo dessa premissa, de uma literatura e cultura, que, de alguma maneira, é permeada pela crueldade, violência e perversidade pretendemos aqui analisar a construção das personagens prostitutas dentro do conto "Putas Asesinas" (2001), de Roberto Bolaño. 


\section{Violência e/ou vingança?}

De acordo com Xavier Crettiez (2011), pensar a respeito da violência, seja ela qual for, política, social, psicológica, etc., está presente no núcleo de toda vida humana. Pensamos a violência o tempo todo, mesmo que inconscientemente. Ao reformarmos nossas casas e elevarmos as alturas dos muros, instalarmos cercas elétricas ou câmeras filmadoras, ao recomendarmos "Cuidado!" ou "Se cuide!" a quem sai de nossas casas, por exemplo, estamos pensando, de alguma forma, a violência.

Presente em nossa vida cotidiana, a violência é difícil de ser definida, aliás como qualquer outro conceito oriundo das ciências humanas. É difícil pensar o humano. Assim, também é difícil pensar a violência se pensarmos que o humano está entre as poucas espécies do reino animal que escraviza o outro, e talvez seja a única que violenta o outro gratuitamente.

A violência não é somente uma ação de coerção; é também uma pulsão que pode ter como finalidade apenas sua expressão, satisfazendo assim certa cólera, ódio, um sentimento negativo, que buscam a se concretizar. O objetivo não é constranger, mas exatamente aviltar, destruir ou se construir pela passagem ao ato. (CRETTIEZ, 2011, p. 11)

Assim, podemos compreender que o homem violenta para satisfazer a si próprio, ou seja, que o homem se torna violento para satisfazer a própria violência que o compõe, que faz parte dele. Dessa forma, iniciamos nosso pensamento acerca do conto "Putas Asesinas", do chileno Roberto Bolaño. O conto faz parte do livro homônimo Putas Aseninas, publicado pela primeira vez em 2001, dois anos antes da morte do escritor.

"Putas Asesinas" narra, para além de qualquer coisa, uma história sobre a vingança. No entanto, não se trata de uma vingança qualquer, destinada a afligir uma vítima que em algum momento no passado foi um algoz, como percebemos em outras histórias de vingança na literatura e que originaram romances grandiosos, como O conde de Montecristo, de Alexandre Dumas, Tieta do Agreste, de Jorge Amado, ou o thriller Carrie, de Stephen King. $\mathrm{Na}$ narrativa criada por Bolaño, a vingança se constrói de forma distinta. As personagens que protagonizaram as narrativas mencionadas, a saber, Edmond Dantés, Tieta e Carrie possuem cada um motivo distinto contra antigos algozes específicos. Há uma motivação contra alguém. Quando se trata da narrativa de Bolaño, o algoz se perde. Trata-se de uma história de vingança na qual a vítima vingativa não tem um alvo certo, não tem um nome ou coisa que o valha que deva ser objeto do ato vingativo.

O enredo de "Putas Asesinas" é, de certo modo, bastante simples: uma prostituta vê, na televisão, um homem que está nas arquibancadas de um estádio de futebol, incentivando o time pelo qual torce. "- Te vi en la televisión, Max, y me dije éste es mi tipo" (BOLAÑO, 2017, p. 111). Então ela segue de moto até o estádio, encontra e se aproxima do tal homem. Ela o seduz, o leva para sua casa e transa com ele. Ao final do ato, ela o amarra na cama, o tortura e o mata com uma navalha.

Ao escrever sobre os vícios e as paixões humanas em O leviatã, Thomas Hobbes (2003, p. 82) se volta para o conceito de vingança ao sugerir que tal ato seria o "[...] desejo de dano 
a outrem, a fim de leva-lo a lamentar qualquer de seus atos.” A assertiva de Hobbes (2003) se volta a um sujeito único que em algum momento causou dano em alguém. Na narrativa de Bolaño, o singular da história é que o homem (cujo nome não é mencionado, mas que é chamado pela mulher de "Max") não lhe causou nenhum dano, ela não o conhece, efetivamente nunca o viu, e ele não fez qualquer mal a ela.

- Como dicen los gángsters, no es nada personal, Max. Por supuesto, en esa aseveración hay algo de verdad y algo de mentira. Siempre es algo personal. Hemos llegado indemnes a través de un túnel del tiempo porque es algo personal. Te he elegido a ti porque es algo personal. Por descontado, nunca antes te había visto. Personalmente nunca hiciste nada contra mí. Esto te lo digo para tu tranquilidad espiritual. Nunca me violaste. Nunca violaste a nadie que yo conociera. Puede incluso que nunca hayas violado a nadie. No es algo personal. Tal vez yo esté enferma. (BOLAÑO, 2017, p. 119)

Percebemos que a personagem culpa sua própria história quando afirma a Max que se trata de algo pessoal, mas não necessariamente com ele. A protagonista se julga doente. A história implica que a prostituta, anteriormente, fora vítima de estupro por outro Max ou por alguém parecido a ele. Por outro lado, pensamos, por conta de tudo o que envolve a narrativa, por todas as justificativas que ela dá ao longo do texto, que se trata de um homem desconhecido, assim como o homem que a violentou, e que ela o mata porque ele se parece com seu agressor. Poderíamos pensar, também, que ela o mata por ele ser homem.

- En realidad verte en la televisión fue como una invitación. Imagina por un instante que yo soy una princesa que espera. Una princesa impaciente. Una noche te veo, te veo porque de alguna manera te he buscado (no a ti sino al príncipe que también tú eres, y lo que representa el príncipe). (BOLAÑO, 2017, p. 111)

É curioso que em todas as cenas, assim como nesta, Max está amarrado e amordaçado, o que sugere a tortura psicológica por parte da narradora, que conta a ele, cruelmente e aos poucos, o motivo de estar naquela situação. A crueldade é uma constante na vida e na natureza humana. Por cruel, em alguns dicionários, encontramos um conceito que gira em torno do desumano ou daquilo que demonstra maldade, opressão. Também se refere ao que se satisfaz praticando o mal, maltratando, atormentando, molestando, ferindo, o que provoca o horror, a repulsa, o sofrimento, a dor, sejam elas de qualquer natureza.

Para José Ovejero (2012, p. 40),

La violencia y la crueldad tienen más fácil aceptación cuando son gratuitas, cuando su significado se agota en la mera narración, que cuando abogan por una moral distinta de la dominante; es decir, son aceptables cuando no empujan a una acción que haga salir al sujeto de sí mismo, abandonando la contemplación o la masturbación. Igual que la pornografía, su función es provocar un efecto físico: hacer subir la adrenalina o lograr excitación del consumidor. 
Notamos que em toda narrativa de Bolaño, a violência e a crueldade impostas pela narradora se faz, exclusivamente, para sua satisfação pessoal, tornando-se partes dela. Dessa forma, ligamos a crueldade e a violência enquanto pertencentes ao ser humano. Assim, nos perguntamos: o que é a violência? Em boa parte dos conceitos oriundos das ciências humanas, não há uma posição de certeza quando ao conceito, pois ele depende do ponto de vista de quem pratica ou recebe a ação violenta. Logo, a violência existirá ou não de acordo com quem narra um ou outro fato. Segundo Jacque Leenhardt (1990, p. 13-14),

O que uns denominam de 'manutenção da ordem', outros vêem como uma manifestação legitima da violência. O que publicitários chamam de 'livre informação do público', outros denunciam como manipulação violenta dos cidadãos, transformados em consumidores alienados.

A palavra jamais compreende, portanto, duas experiências comparáveis porque representa, de qualquer forma, o significante flutuante de todo processo social antagônico.

Torna-se raro, portanto, que o poder fale de si próprio em termos de violência. O poder nunca se descreverá violento. De acordo com Vauvenargue (apud Leenhart, 1990, p.15), "Não há violência, nem usurpação, que não se prevaleça da autorização de alguma lei". No conto de Bolaño, a "lei" não está explicitada em códigos penais ou algo nesse sentido. Porém, para a narradora, existe uma lei de reciprocidade; caçar e assassinar seus algozes se constrói, no conto, como um ponto crítico para a própria narradora, que se regozija ao torturar e assassinar um sujeito que nunca viu na vida.

Apesar de a narrativa mostrar apenas um assassinato cometido pela narradora, é plausível aventar que ela cometeu o ato outras vezes, e cada (possível) assassinato deve ser visto, no (con)texto, como um componente único do sentimento de reciprocidade e de vingança da narradora.

Uma vez desencadeada, a vingança escapa do controle dos homens, ela se perpetua, dissemos, como se fosse dotada de vida própria; enfim, ela é autônoma. E enquanto for autônoma em relação aos homens, priva-os de sua autonomia. O vingador não age por sua própria vontade; ele não tem outra escolha senão matar aquele que matou; ele não é senão o instrumento de uma força que está além dele. (ANSPACH, 2012, p. 31)

No caso da narradora vingativa de "Putas Asesinas", percebemos que, ao ir ao estádio procurar Max, ela obedece a um impulso maior que sua própria vontade. Oscilando entre vítima e algoz, a personagem não vê outra saída senão a procura por aquele sujeito como forma de aplacar, talvez, sua sede de justiça pelo que sofreu. Contudo, se há algum objetivo no ato vingativo, este nunca será o de restaurar aquilo que foi perdido, usurpado ou maculado. A vingança obedece à vontade maior do vingador de sair do papel de vítima, eliminando a coisa ou a pessoa que lhe causou dano, havendo aí uma inversão de papeis entre vítima e algoz. 
Buscando na tradição da literatura hispano-americana as narrativas de vingança, percebemos que o conto de Bolaño possui relação com o célebre conto "Emma Zunz", de Jorge Luis Borges, publicado em 1949 na coletânea El Aleph. "Emma Zunz" nos traz a história de uma operária que recebe uma carta informando-a da morte de seu pai. Emma, suspeitando da culpa do chefe de seu pai, decide se vingar. Assim como na narrativa de Bolaño, Emma Zunz usa seu corpo sedutor para cumprir seu papel de vingadora. Ela seduz o antigo chefe de seu pai, pratica sexo com ele, nesse caso, para não se fazer culpada, e em seguida o mata.

Em contraposição ao conto de Borges, a narrativa de vingança de Bolaño se constrói e vitima Max ao acaso. Por essa razão, em "Putas Asesinas" é firmemente marcado que o acaso é “[...] el mayor criminal que jamás piso la tierra” (BOLAÑO, 2017, p.125). Contudo, uma nuance deve ser apontada: ao mesmo tempo em que o contingente é valorizado, a história assume a retórica de um destino preestabelecido, pois alguém deveria sofrer as sevícias impostas ao tipo torturado, uma vez que a prostituta estava determinada a matar. Na mesma medida da crueldade, existe também um princípio de busca por uma saciedade prazerosa nas atitudes da narradora. Dessa forma, a tensão entre o determinismo e a ação humana sustenta a história.

Se a crueldade emociona, toca o “coração' dos leitores/espectadores, ela é permitida; no entanto, se ela é real, tratada como um assunto a mais dentre tantos outros, ela é rechaçada. A crueldade pertence ao ser humano e se rebela diante de um mundo de aparências; ela luta por uma representação em um mundo real no qual nem tudo é brilho e beleza, ou onde a beleza não está, necessariamente, de mãos dadas com a bondade.

[...] solo el autor cruel es plenamente contemporáneo, porque mientras los demás se dejan cegar por las luces del pasado del futuro o de una concepción ideal de su tiempo, el autor cruel mira la oscuridad de su época, se sumerge en ella, y Ia salva de ser ocultada tras los reflectores. Negar la oscuridad es negar el presente para refugiarse en algún paraíso que nunca se da aquí y ahora, que solo puede existir en un tiempo inalcanzable. (OVEJERO, 2012, p.86-87)

Um autor cruel não oferece certidão, porque não chegou ao fundo da situação, pois não há fundo, e isso é, de alguma maneira, também cruel, pois a queda nunca termina, o cruel nunca termina. Afinal, ele é humano. Assim, como afirma Ovejero (2012), na literatura cruel o leitor deixa de olhar a realidade para olhar-se a si próprio. Eis um dos motivos pelos quais, quando lemos e analisamos essa literatura, percebemos que não há uma completa definição, um mote para suas personagens. O que a caracteriza é que "[...] podrian ser cualquiera (de nosostros)" (OVEJERO, 2012, p. 195).

No conto de Bolaño, o ressentimento assume a dimensão de fobia. Não é apenas a pessoa diretamente responsável por um crime, mas um grupo que é culpado. Todos os homens são culpados aos olhos da narradora. Em "Putas Asesinas", como no filme Monster (2003), dirigido por Patty Jenkins, a mulher estuprada produz um discurso que responsabiliza um grupo. Ao culpar a todos, ela se volta contra todos, se vinga de todos, violenta todos, sem culpa ou arrependimento. Tanto para a narradora de Bolaño como para a assassina de Monster, o homem é um ser imbuído de maldades de todas as espécies e deve ser eliminado. 
Além disso, tanto em Borges, Bolaño e Jenkins, o horizonte de suas histórias é a justificação da violência com base na representação de um Estado ineficiente, incapaz de oferecer justiça. É por isso que, em "Putas Asesinas”, a narradora assume a justiça por conta própria, respondendo ao fato de que a justiça oficial ou está ausente, ou está nas mãos de um poder repressivo, burocrático e indolente (nesse caso, masculino), ou ainda sua ausência responde a uma precariedade social.

Como em Monster e em "Emma Zunz", a narração de "Putas Asesinas" mantém empatia com o vitimizador. A fio condutor e a moral dessa história é que a violência arbitrária gera um certo senso de justiça.

Por meio de uma estrutura em diálogos, "Putas Asesinas" apresenta uma enunciação autoritária, o que não é um defeito, porém parte essencial de sua construção. Max nunca fala; ele é silenciado, anulado. Suas “intervenções” são dadas por um narrador em terceira pessoa que o reduz à categoria de "tipo". Essas marcações também servem para descrever sua morte.

Em outro momento, a narradora assume a voz de Max: ela produz o discurso sobre o que sente e pensa, sobre seu lugar no mundo, sobre seu destino, sobre seu corpo e seus prazeres. Em outras palavras, a narradora exercita em Max certas formas repressivas sob as quais o feminino tem sido historicamente pensado. Existe, assim, um processo consciente de investimento político do mundo na expressão da narradora. A vingança não só ocorre através da violência, mas também é acompanhada por uma retórica e uma poética que a sustentam.

Isso faz sentido se lembrarmos que Max pertence e estava em um espaço historicamente masculino: uma torcida de futebol em um estádio esportivo. Além disso, Max não parece um modelo de civilidade. Ele é uma pessoa preconceituosa. Ele não gosta de negros, ele não gosta de cigarros. Ele é um macho que é atraído por prostitutas. E talvez, também por isso, a narradora o mate.

- Tú no sabes nada de pintura, Max, pero intuyo que sabes mucho de soledad. Te gustan mis Reyes Católicos, te gusta la cerveza, te gusta tu patria, te gusta el respeto, te gusta tu equipo de fútbol, te gustan tus amigos o compañeros o camaradas, la banda o grupo o pandilla, el pelotón que te vio quedarte rezagado hablando con una tía buena a la que no conocías, y no te gusta el desorden, no te gustan los negros, no te gustan los maricas, no te gusta que te falten al respeto, no te gusta que te quiten el sitio. En fin, son tantas las cosas que no te gustan que en el fondo te pareces a mí. (BOLAÑO, 2017, p. 118)

O momento da morte de Max mostra outros aspectos da expressão da prostituta: sua tendência a usar imaginários literários emprestados da tradição (o príncipe, a princesa, o castelo) e invocar figuras de poder como os Reis Católicos. Em outras palavras, ela embeleza a violência e politiza os espaços, acrescentando um certo tom providencial e conservador à sua história.

"A violência é um aspecto inevitável da história, mas secundário e derivado. Não é o emprego da violência que produz as transformações sociais, são as transformações sociais 
que passam pela violência" (MICHAUD, 2001, p. 96). Se há transformações no meio social que passam pela violência, há também transformações pessoais que passam por ela: “[...] de um lado, o termo 'violência' designa fatos e ações; de outro, designa uma maneira de ser da força, do sentimento ou de um elemento natural - violência de uma paixão ou da natureza" (MICHAUD, 2001, p. 7). A narradora de Bolaño, assim como em outras narrativas de vingança feminina, necessariamente, não quer mudar o mundo e fazer com que os homens mudem suas atitudes e passem a respeitar as mulheres; o que elas desejam é uma satisfação pessoal.

O prazer de matar existe? A voga dos filmes americanos que não param de fazer com que o inimigo interior seja percebido como um serial killer, tão fisicamente violento quando moralmente ambíguo, favorece uma interpretação psicanalítica da entrada da violência. [...] - a neurose criminosa é provavelmente uma realidade em alguns indivíduos que sentem, com o sofrimento do outro, uma forma de prazer, e até um vício agradável. (CRITTIEZ, 2011, p. 99).

A narradora de "Putas Asesinas" sente prazer em torturar Max, pois para ela há relação entre o sujeito que ela encontrou no estágio e o que a violentou. A postura de viúva negra, aquela que seduz para matar, se encaixa à intenção da narradora. Ela precisa se vingar de todos os homens, e sua grande arma é ela mesma, seu próprio corpo, desejado e objetificado. A narradora dedica-se sexualmente aos homens, aplacando seus desejos, os mais obscuros e, em troca, lhes rouba a vida.

Também é relevante notar que, na parte final do conto, a narradora, ainda torturando Max, se conecta a todas as mulheres vítimas masculinas, aos estereótipos que o imaginário popular cria delas e aos desejos que elas têm de rebelar-se contra um sistema criado pelos homens e, quiçá, por elas próprias.

Tus palabras, lo reconozco, han sido amables. Temo, sin embargo, que no has pensado suficientemente bien lo que decías. Y menos aún lo que yo decía. Escucha siempre con atención, Max, las palabras que dicen las mujeres mientras son folladas. Si no hablan, bien, entonces no tienes nada que escuchar y probablemente no tendrás nada que pensar, pero si hablan, aunque sólo sea un murmullo, escucha sus palabras y piensa en ellas, piensa en su significado, piensa en lo que dicen y en lo que no dicen, intenta comprender qué es lo que en realidad quieren decir. Las mujeres son putas asesinas, Max, son monos ateridos de frío que contemplan el horizonte desde un árbol enfermo, son princesas que te buscan en la oscuridad, llorando, indagando las palabras que nunca podrán decir. En el equívoco vivimos y planeamos nuestros ciclos de vida. Para tus amigos, Max, en ese estadio que ahora se comprime en tu memoria como el símbolo de la pesadilla, yo sólo fui una buscona extraña, un estadio dentro del estadio, al que algunos llegan después de bailar una conga con la camiseta enrollada en la cintura o en el cuello. Para ti yo fui una princesa en la Gran Avenida fragmentada ahora por el viento y el miedo (de tal modo que la avenida en tu cabeza ahora es el túnel del tiempo), el 
trofeo particular después de una noche mágica colectiva. Para la policía seré una página en blanco. Nadie comprenderá jamás mis palabras de amor. (BOLAÑO, 2017, p. 120-121)

Ao reconhecer as palavras amáveis de Max, recheadas de intenções, a narradora também reconhece que para ele não importa quem ela seja ou o que diga desde que satisfaça seus desejos. Não importa quem ela é, o que pensa ou sente. A narradora se vinga, em Max, de todos os homens. No passado da formação da sociedade, o feminino é movido pelo "fetiche”, aquilo que deve ser dominado, e para tal, há de se estar em grupo. Não se domina uma mulher sozinho. O "tipo" que violentou a narradora não a dominou sozinha; ele teve o auxílio de toda uma sociedade construída para a dominação das mulheres. Ao escolher um homem em um estádio de futebol, ambiente predominantemente masculino, e que estava acompanhado por seus amigos, ela, a solitária puta assassina, subverte a construção de um feminino violentado, rechaçado e rebaixado, passando a outro patamar. De caça dos homens que não enfrentam mulheres sozinhos, a caçadora solitária tortura e mata o que para ela é o mal do mundo: os homens.

\section{REFERÊNCIAS}

ANSPACH, Mark. Anatomia da Vingança: figuras elementares de reciprocidade. Trad. Margarita Maria Garcia Lamelo. São Paulo: É Realizações, 2012.

BARTHES, Roland. Efeito de real. In: Vários autores. Literatura e semiologia. Petrópolis: Vozes, 1971.

BARTHES, Roland. O prazer do texto. Trad. J. Guinsburg, 3. ed. São Paulo: Perspectiva, 2002.

BOLAÑO, Roberto. Putas aseninas. Barcelona: Vintage Español, 2017.

BROTHERSTON, Gordon. La visión americana de la conquista. In: PIZARRO, Ana. América Latina: palabra, literatura e cultura. Campinas: Unicamp,1993.

CANDIDO, Antonio. Literatura e Sociedade. Rio de Janeiro: Ouro sobre azul, 2014.

CRETTIEZ, Xavier. Las formas de la violencia. Buenos Aires: Waldhuter, 2009.

GALEANO, Eduardo. La venas abiertas de América Latina. Barcelona: Siglo Veintiuno Editores, 2011.

GINZBURG, Jaime. Literatura, violência e melancolia. Campinas, SP: Autores Associados, 2012.

GRAMUGLIO, Maria Teresa. El imperio realista. Tomo 6. Noé Jitrik (Dir.) Historia crítica de la literatura argentina. Buenos Aires: Emecé, 2002. 
HOBBES, Thomas. O Leviatã. Trad. João Paulo Monteiro e Maria Beatriz Nizza da Silva. São Paulo: Martins Fontes, 2003.

JAKOBSON, Roman. Do realismo na arte. In.: TODOROV, Tzvetan. Teoria da literatura: textos dos formalistas russos. Trad. Roberto Leal Ferreira. $1^{\text {a }}$ ed. São Paulo: Editora UNESP, 2013.

LIENHARD, Martin. Los comienzos de la literatura "latinoamericana": monólogos y diálogos de los conquistadores y conquistados. In: PIZARRO, Ana. América Latina: palabra, literatura e cultura. Campinas: Unicamp,1993.

LINS, Ronaldo Lima. Violência e literatura. Rio de Janeiro: Tempo Brasileiro, 1990.

MICHAUD, Yves. A violência. Trad. L. Garcia. São Paulo: Ática, 2001.

OVEJERO, José. La ética de la crueldad. Barcelona: Editorial Anagrama, 2012

ROUDINESCO, Elisabeth. A parte obscura de nós mesmos: uma história dos perversos. Trad. André Telles. Rio de Janeiro: Zahar, 2008.

WELLEK, René, WARREN, Austin. Teoria da literatura.4a ed. Lisboa: Europa-América, s.d. 